\title{
Pengaruh Behavioral Finance Terhadap Pengambilan Keputusan Hutang di Era Covid- 19: Studi Kasus Pada UMKM Sektor Makanan di Kota Bandung
}

\author{
Tuti Anggraeni' ${ }^{1}$, Nugraha ${ }^{2}$, Maya Sari ${ }^{3}$, Dodi Sukmayana ${ }^{4}$ \\ ${ }^{1,2,3}$ Universitas Pendidikan Indonesia, Bandung, Indonesia \\ ${ }^{4}$ Universitas Winaya Mukti, Bandung, Indonesia \\ Email corresponding author: tutianggraeni01@upi.edu
}

\begin{abstract}
ABSTRAK
Tujuan penelitian ini adalah untuk menganalisis pengaruh bevaioral finance dengan mengunakan factor bias overconfidence terhadap pengambilan keputusan hutang pada UMKM dan pengaruh behavioural finance dengan menggunakan factor bias illusion of control terhadap pengambilan keputusan hutang pada UMKM. Penelitian ini merupakan penelitian berbasis kuantitatif, dengan jenis metoda penelitian yang dipakai adalah Regresi Linier Berganda. Penelitian ini menggunakan 59 sampel pelaku usaha UMKM sector makanan yang berada di wilayah Kota Bandung. Teknik pengambilan sampel yang dipilih dalam penelitian ini adalah dengan cara teknik sampling insidental dan pengumpulan data menggunakan kuesioner yang disebarkan kepada responden yaitu pelaku sekaligus pemilik UMKM. Teknik analisis data yang digunakan dalam penelitian ini adalah regresi linear berganda. Hasil penelitian menunjukkan adanya pengaruh overconfidenceyang signifikan terhadap pengambilan keputusan hutang disaat era pandemic covid-19 yang dilakukan oleh pelaku usaha UMKM sector makanan yang berada di wilayah Kota Bandung. Dan hasil penelitian pun menujukan bahwa ada pengaruh signikan dari factor bias illusion of control terhadap pengambilan keputusan hutang disaat era pandemic covid-19 yang dilakukan oleh pelaku usaha UMKM sector makanan yang berada di wilayah Kota Bandung.Keputusan Berhutang yang dilakukan pelaku UMKM sector makanan di kota Bandung ini dipengaruhi oleh karakteristik responden yang memiliki usia produktif 36 sampai dengan 40 tahun, sebagian besar perempuan dengan latar belakang Pendidikan perguruan tinggi yang sudah menggeluti usaha lebih dari 5 tahun.
\end{abstract}

Kata Kunci: Overconfidence, illusion of control, Penggambilan Keputusan, Covid-19

\section{ABSTRACT}

The purpose of this study is to analyze the effect of behavioral finance by using the overconfidence bias factor on debt decision making in MSMEs and the influence of behavioral finance by using the illusion of control bias factor on debt decision making in MSMEs. This research is a quantitative-based research, with the type of research method used is Multiple Linear Regression. This study uses 59 samples of food sector MSME business actors in the Bandung City area. The sampling technique chosen in this study was incidental sampling technique and data collection using a questionnaire distributed to respondents, namely the perpetrators and owners of MSMEs. The data analysis technique used in this research is multiple linear regression. The results showed that there was a significant overconfidence effect on debt decision making during the covid-19 pandemic era carried out by food sector MSME business actors in the Bandung City area. And the results of the study also show that there is a significant influence from the illusion of control bias factor on debt decision making during the covid-19 pandemic era carried out by food sector MSME business actors in the Bandung City area. Debt decisions made by food sector MSME actors in the city Bandung is influenced by the characteristics of respondents who have a productive age of 36 to 40 years, 
most of them are women with a university education background who have been in business for more than 5 years.

Keywords: Overconfidence, illusion of control, Decision Making, Covid-19

\section{PENDAHULUAN}

Kota Bandung salah satu kotamadya yang berkembang dalam program UMKM. Karena itu, pemerintah daerah fokus mengembangkan UMKM yang dikelola kementrian koperasi dengan cara memberi pelatihan, memberikan pendampingan usaha bahkan membantu sebagian modal bagi UMKM yang baru membuka usaha. Namun kenyataannya tidak semua UMKM di Bandung ini memiliki produktivitas yang tinggi. Ada banyak UMKM yang rendah produktivitasnya. Rendahnya produktivitas umkm dapat terlihat dari pendapatan yang masih rendah, jumlah produksi barang tidak mengalami peningkatan dan sempitnya area pemasaran produk jadi UMKM.

Dinas Koperasi, Usaha Mikro, Kecil, dan Menengah (KUMKM) mencatat terjadi pertumbuhan UMKM di Kota Bandung sebesar 3.8\% dalam kurun waktu enam tahun terakhir. Kasie Pemberdayaan dan Pengembangan Usaha Mikro dan Fasilitasi Dinas KUMKM Kota Bandung, Nuri Nuraeni mengatakan, jumlah usaha mikro berdasarkan data BPS Kota Bandung sebanyak 111.627 atau 75\% dari jumlah total kelompok UMKM 147.073. Adapun jumlah UMKM binaan terdaftar pada Dinas KUMKM yakni 6.409. Adanya pandemi Covid-19 berdampak pada semua negara di dunia, tidak sedikit negara yang mengalami resesi karena pertumbuhannya negatif. Perekonomian global terkontraksi yang mengakibatkan tingginya ketidak pastian. Di Indonesia, pertumbuhan PDB triwulan II 2020 terkontraksi sebesar 5,32\% di bandingkan dengan triwulan kedua tahun 2019 (yearon-year), bila dibandingkan dengan triwulan pertama tahun 2020 (quartal-to-quartal) ekonomi Indonesia terkontraksi sebesar 4,19\% (BPS, Agustus 2020). Menurut Kemenkop UKM, sampai dengan awal Juni 2020 UMKM yang terdampak pandemi Covid-19 yang paling banyak adalah UMKM kuliner. Hal tersebut tentunya juga dialami oleh UMKM Makanan yang ada di Kota Bandung. Adanya larangan dan pembatasan berjualan oleh Pemkot Bandung, adanya social distancing dan pemberlakuan work from home pada kurun waktu tiga sampai empat bulan awal terjadinya pandemi Covid-19 mengakibatkan daya beli masyarakat turun dan berdampak pada penurunan pendapatan keuangan UMKM Makanan.

Nuri membeberkan kendala yang dihadapi pihaknya selama pandemi Covid-19 yang sudah berlangsung satu tahun terakhir. Mulai dari minimnya modal, hingga kurangnya inovasi produk. "Minimnya Modal menjadi permasalahan umum para pelaku usaha mikro. Pengelolaan keuangan yang tidak efisien juga menjadi salah satu kendala usaha mikro sulit untuk berkembang". Permasalahan internal yang paling dominan dihadapi adalah keterbatasan sumber pendanaan.Reid (1997)mengungkapkan bahwa sumber pendanaan yang berasal hutang dan injeksi keuangan daripemilik sama-sama memiliki efek yang signifikan bagi kelanjutan usaha. Menurut Gibson(2001), hubungan antara sumber pendanaan yang berasal dari modal sendiri dan hutang padamikro dan kecil yang dimiliki perorangan seringkali bersifat kompleks karena aset pemilikdigunakan sebagai jaminan hutang, pemilik menghadapi risiko untuk return yang belum pasti.

Preferensi terhadap hutang sebagai sumber pendanaan juga dianalisis melalui pendekatan keuangan perilaku (behavioral finance) yang menekankan bahwa seseorang sering berperilaku tidak rasional jika membuat keputusan yang melibatkan uang karena faktor psikologis lebih berperan dalam pengambilan keputusan keuangan (Hirchey and Nofsinger, 2008). Keputusan yang lebih didominasi oleh faktor psikologis akan mengarah pada hasil keputusan yang bias karena faktor rasa yang ada pada diri seseorang melebihi pertimbangan 
faktor rasio. Shefrin (2007) mengidentifikasi berbagai faktor psikologis atau disebutnya fenomena psikologis, yang terbagi ke dalam tiga kategori meliputi bias, heuristic dan framing effect. Ada dua yang menjadi variabel dalam penelitian ini yaitu overconfidence, danillusion of control. Hal ini berdasarkan penelitian Supramono dan Putlia (2010) yang menyatakanbahwa aspek psikologis tersebut yang dominan membuat pengusaha mengedepankanfaktor emosional daripada kalkulasi ekonomi sehingga menghasilkan keputusan yang bias.Pengambilan keputusan yang irrationality merupakan perilaku manusia yangbertentangandengan asumsiasumsi yang mendasari model ekonomi klasik dalampengambilan keputusan yang banyak berpedoman pada rationality.

\section{KAJIAN TEORITIS DAN KAJIAN EMPIRIK}

De Bondt, et al. (2008) menyatakan "Behavioral finance is the studyof how psychology impacts financial decisions in households, marketand organizations", yang artinya studi tentangbagaimana psikologi berdampak pada keputusan-keputusan keuangan di dalam rumah tangga, pasar dan organisasi. Sedangkan menurut Pompian (2006) Behavioral Finance, commonlydefined as theapplication of psychology to finance. Shefrin's (2005) dalam Forbes (2009) Behavioralfinance is the study of how psychological phenomena impact financial behavior. Sedangkan menurut Lintner (1998:7), behaviouralfinance"the study of humans interpret and acton information to makeinformed investment decisions" artinya, keuangan perilaku merupakan ilmu yang mempelajaribagaimana manusia menginterpretasikan dan bertindak terhadap informasi untuk membuatkeputusan dalam berinvestasi. Jadi unsur sikap dan tindakan manusia merupakan factorpenentu dalam berinvestasi. Sehingga Behavioral finance, secara sederhana dapat didefinisikansebagai aplikasi dari psikologi ke dalam disiplin ilmu keuangan dalam pengambilankeputusan keuangan di dalam rumah tangga, pasar dan organisasi.

Ricciardi dan Simon (2000) dalam Gumanti, (2009:9) membagi empat tema utama yangtercakup dalam keuangan perilaku.

\section{Overconfidence Theory}

Keyakinan berlebihan sudah menjadi salah satu topik menarik yang mendapatkan perhatian luas dari para peneliti dibidang psikologis dan keuangan perilaku.Sebagai manusia, tidak dapat disangkal bahwa pengusaha atau manajer memiliki kecenderungan untuk terlalu yakin atas kemampuan dan prediksi untuk berhasil.Kondisi ini merupakan hal yang normal yang sekaligus merupakan cermin dari tingkat keyakinan seseorang untuk mencapai atau mendapatkan sesuatu.Keyakinan yang berlebihan juga muncul dari sudut pandang bidang pemasaran.

\section{Financial Cognitive Dissonance Theory}

Teori ketidakberaturan kognitif keuangan (financial cognitive dissonance) yang dikembangkan oleh Festinger dalam Morton (1993) dalam Gumanti (2009:10), menyatakan bahwa manusia merasakan tekanan internal dan keraguan atau ketakutan manakala dihadapkan pada benturan atau perbedaan keyakinan. Sebagai individu, sebaiknya mencoba untuk mengurangi konflik internal yang ada pada diri (mengurangi dissonance) setidaknya dengan satu dari dua cara berikut, yaitu (1) merubah nilai masa lalu, perasaan atau opini, dan (2) mencoba untuk merasionalisasi pilihan-pilihan. 


\section{Regret Theory}

Teori penyesalan (regret theory) menyatakan bahwa individual melakukan evaluasi reaksi harapan pada suatu kejadian atau situasi di masa depan. Bell (1982) menggambarkan penyesalan (regret) sebagai emosi yang disebabkan oleh perbandingan pada suatu keluaran tertentu (a given outcome) atau suatu kejadian dengan sesuatu yang tidak jadi dipilih (foregone choice).

\section{Prospect Theory}

Teori prospek (prospect theory) berkaitan dengan ide bahwa manusia tidak selalu berperilaku secara rasional. Teori ini beranggapan bahwa ada bias yang melekat dan terus ada yang dimotivasi oleh faktor-faktor psikologi yang mempengaruhi pilihan orang dibawah kondisi ketidakpastian. Teori prospek mempertimbangkan preferensi sebagai suatu fungsi timbangantimbangan keputusan dan berasumsi bahwa timbangan-timbangan keputusan dan berasumsibahwa timbangan-timbangan tersebut tidak selalu tepat dengan probabilitas.Secara spesifik,teori prospek berpendapat bahwa timbangan-timbangan cenderung lebih tinggi daripadaprobabilitas yang rendah dan lebih rendah daripada probabilitas yang moderat atau tinggi.

Overconfidence adalah salah satu psychological bias dalam pengambilan keputusan yangberkaitan dengan keyakinan yang dimiliki seseorang dengan kemampuan dan pengetahuan yang dimiliki diatas rata-rata.Hal ini dibuktikan oleh penelitian yang dilakukan oleh Statman,Thorley dan Vorkink (2006) yang menyatakan bahwa investor yang overconfidence dapatdijelaskan dengan adanya volume perdagangan yang tinggi. Dengan bias yang ada didalamdiri investor, volume perdagangan bervariasi dengan tingkat pengembalian, artinya tidakselalu volume perdagangan tinggi diikuti pengembalian yang tinggi. Bahkan dalam analisispenelitian yang dilakukan oleh Grinblatt dan Keloharju (2009) tidak ditemukan hubunganantara overconfidence dengan perputaran perdagangan.Sedangkan penelitian yang dilakukanoleh Ishikawa dan Takashashi, 2010) menyatakan bahwa manajer pada perusahaan yangterdaftar di Jepang cenderung overconfidence.Hal ini terbukti dengan kecenderungan yangstabil untuk memprediksi laba yang terlalu tinggi dibandingkan dengan yang sebenarnya.Eichholtz dan Yonder (2011) juga membuktikan bahwa keputusan yang overconfidencemempunyai pengaruh negatif terhadap kinerja perusahaan. Penelitian Friedman (2007) menekankan pada keputusan wirausaha, yang menyatakan bahwa overconfidence dalam pengambilan keputusan juga dapat dilihat pada keputusan wirausaha dalam memulai usaha.

Mereka tidak menggunakan dana yang bersumber dari luar untuk menjalankan usahanya. Kaitannya dengan modal kerja, Ramiah, et al. (2012) menyatakan bahwa overconfidence merupakan salah satu aspek bias yang apabila digunakan dengan benar dapat meningkatkan efisiensi modal kerja. Artinya tidak selalu overconfidence mempunyai makna negatif. Illusion of control adalah kecenderungan manusia percaya bahwa mereka dapat mengontrol atau paling tidak mempengaruhi hasil tetapi pada kenyataannya mereka tidak dapat.Dimana pada umumnya seseorang merasa mampu mengendalikan hasil dari keputusan yang diambilnya. Kepercayaan pengusaha dapat memiliki pengaruh terhadap hasil, sehingga investor menaksir terlalu tinggi control yang mereka miliki terhadap hasil (Nofsinger, 2005).Sedangkan menurut Shefrin (2007) mengemukakan bahwa ketika seorang manajer membuat suatu keputusan, hasil yang diperoleh merupakan kombinasi dari keterampilan yang dipunyai dan keberuntungan. 


\section{METODOLOGI PENELITIAN}

\section{Objek dan Subjek Penelitian}

Penelitian ini dilakukan di Provinsi Jawa Barat khususnya kawasan Kota Bandung, alasan utama dari pemilihan lokasi ini adalah jumlah usaha mikro kecil dan menengah di kota bandung sangat banyak berdasarkan data dari Kasie Pemberdayaan dan Pengembangan Usaha Mikro dan Fasilitasi Dinas KUMKM Kota Bandung, Nuri Nuraeni mengatakan, jumlah usaha mikro berdasarkan data BPS Kota Bandung sebanyak 111.627 atau $75 \%$ dari jumlah total kelompok UMKM 147.073. Adapun jumlah UMKM binaan terdaftar pada Dinas KUMKM yakni 6.409 (data per 20 september 2021). Adapun Populasi yang diambil sebanyak 144 UMKM binaan sector UMKM makanan.

Adapun subjek penelitian ini adalah pemilik UMKM makanan yang berada di daerah kota Bandung. Penelitian ini merupakan penelitian berbasis pendekatan kuantitatif, dengan jenis penelitian explanatory research yang menganalisis pengaruh satu variabel terhadap variabel lainnya. Objek dari penelitian ini adalah menganalisis Overconfidence, dan Illusion of Control terhadap pengambilan Keputusan Hutang pada UMKM sector makanan di Kota Bandung.

\section{Aplikasi Penerapan Kajian Terhadap Objek}

Data primer dalam penelitian ini adalah data yang dikumpulkan dengan menyebar kuisioner dan didukung dengan hasil wawancara dengan responden dan data sekunder penelitian ini adalah data dari Disperindang Povinsi Jawa Barat. Populasi dalam penelitian ini adalah seluruh usaha mikro, kecil dan menengah yang terdapat di wilayah Kota Bandung. Teknik pengambilan sampel yang dipilih dalam penelitian ini adalah dengan cara teknik sampling insidental yaitu prosedur Teknik penentuan sampel berdasarkan kebetulan, siapa saja yang secara kebetulan/insidental bertemu dengan peneliti dapat digunakan sebagaisampel, bila dipandang orang yang kebetulan ditemui itu cocok sebagai sumber data.Cara menentukan jumlah anggota sampel dari suatu populasi dalam penelitian ini menggunakan rumus Slovin (Sugiarto, 2003:81), yaitu :

$$
\mathrm{n}=\frac{\mathrm{N}}{1+\left(\mathrm{N}+\mathrm{e}^{2}\right)}
$$

Jumlah populasi yang diambil dalam penelitian ini sebanyak 144 UMKM makanan dan jumlah sampel sebanyak 59 UMKM makanan .

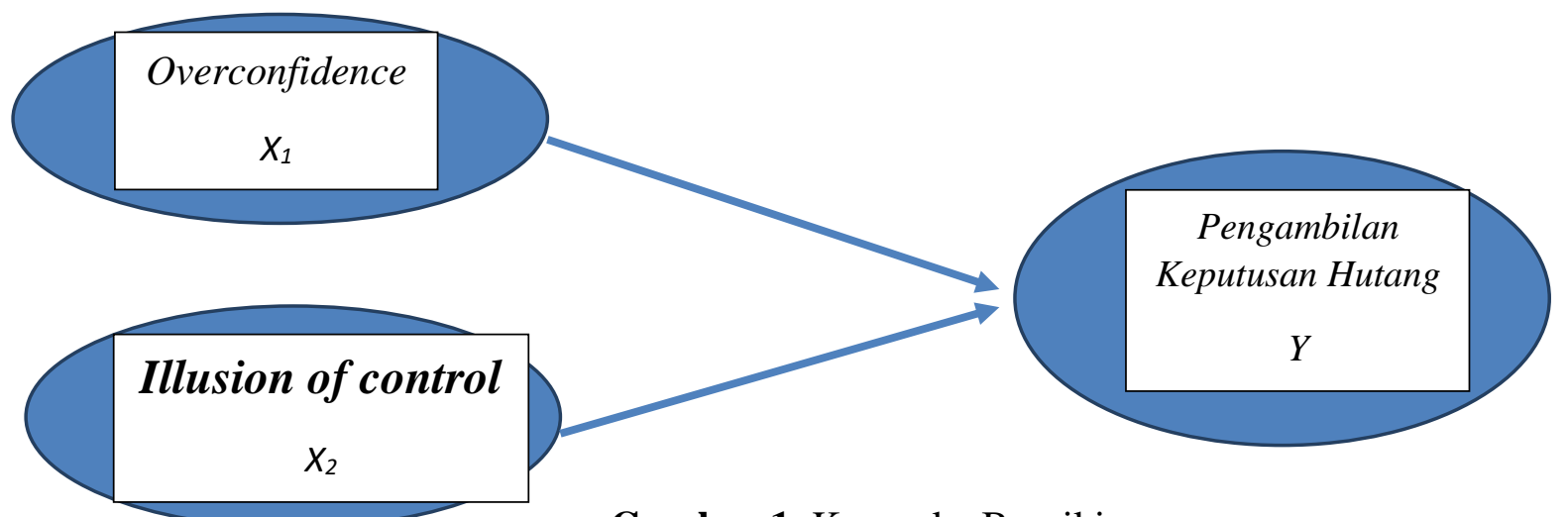

Gambar 1. Kerangka Berpikir

Adapun hipotesis yang diuji dalam penelitian ini adalah:

H1 :Overconfidence berpengaruh signifikan terhadap Pengambilan Keputusan Hutang di UMKM. 
H2 :Illusion of Control berpengaruh signifikan terhadap Pengambilan keputusan Hutang di UMKM.

DalamPenelitian ini menggunakan 2 variabel bebas $(\mathrm{X})$ yaitu Overconfidence $\left(X_{1}\right)$ dan Illusion of Control $\left(X_{2}\right)$. Masing-masing variabel mempunyai tiga indikator dan setiap indikator mempunyai satu item pernyataan. Semua indikator yang digunakan pada penelitian ini bersifat refleksif. Indikator dan item yang dimaksud ditunjukkan dalam tabel dibawah ini:

Tabel 1. Indikator dan Item Variabel Bebas

\begin{tabular}{|l|l|l|l|}
\hline No & Variabel & Indikator & \multicolumn{1}{l}{ Item } \\
$\mathbf{1 .}$ & $\begin{array}{l}\text { Overconfidence } \\
\text { adalahsikap manajeryang } \\
\text { merasa yakin dirinya } \\
\text { memiliki kemampuan } \\
\text { danpengetahuan } \\
\text { diatasrata-rata. }\end{array}$ & $\begin{array}{l}\text { - Kemampuanmelunasihutang } \\
\text { - Kemampuanmenanggung } \\
\text { bebanbunga } \\
\text { - Percaya mampumelunasi } \\
\text { sesuaidengan jangka } \\
\text { waktupengembalian yangtelah } \\
\text { ditetapkan }\end{array}$ & $\begin{array}{l}\text { - Saya yakin mampumenanggung } \\
\text { bebanbunga } \\
\text { - Saya percaya mampumelunasi } \\
\text { sesuaidengan jangka } \\
\text { waktupengembalian yangtelah } \\
\text { ditetapkan }\end{array}$ \\
\hline $\mathbf{2}$ & $\begin{array}{l}\text { Illusion of Control adalah } \\
\text { sikap manajeryang } \\
\text { merasa yakin } \\
\text { mampumengendalikan } \\
\text { atau mempengaruhihasil } \\
\text { suatu keputusan } \\
\text { yangdiambil. }\end{array}$ & $\begin{array}{l}\text { - Terlibat menentukanpilihan } \\
\text { secara aktif } \\
\text { - Familiar terhadaphutang } \\
\text { - Memiliki informasihutang yang } \\
\text { cukuplengkap }\end{array}$ & $\begin{array}{l}\text { - Saya selalu terlibatmenentukan } \\
\text { pilihansecara aktif } \\
\text { - Saya merasa familiarterhadap } \\
\text { hutang } \\
\text { - Saya merasa sudahmemiliki } \\
\text { informasihutang yang cukup }\end{array}$ \\
\hline
\end{tabular}

Sumber : Supramono dan Putlia (2010)

Sedangkan Variabel tak bebas $(Y)$ yaituPengambilan Keputusan Hutang, diukur dengan menggunakan indikator-indikator yang bersifat refleksif. Adapun indikator dan itemnyaditunjukkan dalam table dibawah ini:

Tabel 2. Indikator dan Item Variabel Pengambilan Keputusan Hutang

\begin{tabular}{|c|c|c|}
\hline No & Indikator & Item \\
\hline 1 & Dukungan Keuangan & $\begin{array}{l}\text { Pendanaan dari hutang mendukung keuangan dariusaha yang } \\
\text { saya lakukan }\end{array}$ \\
\hline 2 & Produktif dan Disiplin & $\begin{array}{l}\text { Hutang membuat saya menjadi produktif dan } \\
\text { disiplin dalam melaksanakan usaha }\end{array}$ \\
\hline 3 & $\begin{array}{l}\text { Manfaat hutang lebih besar } \\
\text { daripadarisiko }\end{array}$ & Saya merasa manfaat hutang lebih besar daripadarisikonya \\
\hline 4 & Dipercaya pihak lain & $\begin{array}{l}\text { Dengan mendapatkan hutang berarti saya masih } \\
\text { dipercaya pihak lain }\end{array}$ \\
\hline 5 & $\begin{array}{l}\text { Hati-hati dalam pengelolaan dan } \\
\text { penggunaan uang }\end{array}$ & $\begin{array}{l}\text { Hutang membuat saya hati-hati dalam pengelolaandan } \\
\text { penggunaan uang }\end{array}$ \\
\hline
\end{tabular}

Sumber : Supramono dan Putlia (2010)

\section{Pengukuran Variabel}

Skala Likert digunakan untuk mengukur variabel eksogen dan endogen. Variabel yang akan diukur dijabarkan menjadi indikator. Hubungan antar variabel tersebut di atas dirumuskan dalam hipotesis penelitian yang akan diuji kebenarannya. Dengan kata lain penelitian ini bertujuan untuk menguji hipotesis. Pengukuran variabel ini dilakukan dengan skala Likert yang dituangkan dalam bentuk pilihan jawaban angket, yaitu: a. Sangat tidak setuju (skor 1); b. Tidak Setuju (skor 2); c. Netral (Skor 3); d. Setuju (skor 4); e. Sangat setuju (skor 5). 


\section{Jenis dan Sumber Data}

Jenis data yang digunakan dalam penelitian ini adalah: Data Kualitatif, seperti sikap manajer keuangan dalam pengambilan keputusan hutang yang berkaitan dengan Overconfidence dan Illusion of Control.Sumber Data yang digunakan adalah Data primer, yaitu data yang diperoleh langsung dari obyek penelitian, yang berupa jawaban dari pernyataan yang ada di angket.

\section{Teknik Pengumpulan Data}

Teknik pengumpulan data yang digunakan dalam penelitian survei ini adalah dengan menggunakan angket, yaitu daftar yang mencakup semua pernyataan yang akan digunakan.

\section{Alat Analisis}

Untuk mencapai tujuan penelitian serta pengujian hipotesis, maka data yang diperoleh akan diolah sesuai dengan kebutuhan analisis. Alat analisis yang digunakan dalam penelitian ini adalah analisis Regresi Linier Berganda.

\section{Karakteristik Responden}

\section{HASIL DAN PEMBAHASAN}

Karakteristik responden penelitian ini dikelompokkan berdasarkan umur, jenis kelamin, dan pendidikan.

Tabel 4. Karakteristik Respon Penelitian

\begin{tabular}{|c|c|c|c|}
\hline \multirow[t]{2}{*}{ Karakteristik } & \multirow[t]{2}{*}{ Katagori } & \multicolumn{2}{|c|}{ Jumlah responden } \\
\hline & & Orang & $\%$ \\
\hline \multirow[t]{7}{*}{ Umur } & $20 \mathrm{~s} / \mathrm{d} 25$ th & 4 & 6.77 \\
\hline & $26 \mathrm{~s} / \mathrm{d} 30$ th & 8 & 13.55 \\
\hline & $31 \mathrm{~s} / \mathrm{d} 35$ th & 5 & 8.47 \\
\hline & $36 \mathrm{~s} / \mathrm{d} 40$ th & 32 & 54.23 \\
\hline & $41 \mathrm{~s} / \mathrm{d} 45$ th & 3 & 5.08 \\
\hline & $>45$ th & 7 & 11.86 \\
\hline & Total & 59 & 100 \\
\hline \multirow[t]{3}{*}{ Jenis Kelamin } & Laki-laki & 23 & 38.98 \\
\hline & Perempuan & 36 & 61.02 \\
\hline & Total & 59 & 100 \\
\hline \multirow[t]{7}{*}{ Tingkat Pendidikan } & $\mathrm{S} 2$ & 3 & 5.11 \\
\hline & $\mathrm{S} 1$ & 23 & 38.98 \\
\hline & D3 & 6 & 10,16 \\
\hline & SMA/sederajat & 17 & 28.81 \\
\hline & SMP/sederajat & 8 & 13.56 \\
\hline & Lainnya & 2 & 3.38 \\
\hline & Total & 59 & 100 \\
\hline
\end{tabular}

Sumber: Data Primer,hasil olahan

\section{Uji Validasi dan Reabilitas}

Pengujian validitas menunjukan sejauh mana ukuran tersebut dapat digunakan untuk mengukur apa yang seharusnya diukur Sugiyono (2007). Valid tidaknya suatu instrument dapat dilihat dari Product moment korelation (r-hitung)> 0,5 Sugiyomo (2012). Uji Validitas dapat dilihat pada table dibawah ini. 
Tabel 5. Uji Validitas

\begin{tabular}{|c|c|c|c|c|}
\hline Variabel & Indikator & $\mathrm{r}$ hitung & Sig. & Keterangan \\
\hline Overconfidence & $\mathrm{X}_{1.1}$ & 0,643 & 0,000 & Valid \\
$\mathrm{X}_{1}$ & $\mathrm{X}_{1.2}$ & 0,611 & 0,000 & Valid \\
& $\mathrm{X}_{1.3}$ & 0,637 & 0,000 & Valid \\
\hline Illusion of Control & $\mathrm{X}_{2.1}$ & 0,824 & 0,000 & Valid \\
$\mathrm{X}_{2}$ & $\mathrm{X}_{2.2}$ & 0,807 & 0,000 & Valid \\
\hline Pengambilan Keputusan & $\mathrm{X}_{2.3}$ & 0,796 & 0,000 & Valid \\
\hline Hutang & $\mathrm{Y}_{1}$ & 0,622 & 0,000 & Valid \\
\hline$Y$ & $\mathrm{Y}_{2}$ & 0,668 & 0,000 & Valid \\
& $\mathrm{Y}_{3}$ & 0,771 & 0,000 & Valid \\
\hline
\end{tabular}

Sumber: data diolah

Berdasarkan Tabel 5di atas, dapat diketahui bahwa instrumen penelitian yang digunakan memiliki skor product moment lebih dari 0.5 dengan taraf signifikansi kurang dari 5 persen sehingga semua butir dalam instrument dikatakan valid. Pengujian realibilitas bertujuan untuk mengetahui keandalan alat ukur atau dengan kata lain alat ukur tersebut konsisten jika digunakan untuk mengukur objek yang sama lebih dari dua kali. Instrument yang reliabel adalah instrument yang digunakan beberapa kali untuk mengukur objek yang sama akan menghasilkan data yang sama Ghozali(2006). Dengan kata lain, pengukuran yang memiliki reliabilitas tinggi, adalah yang mampu memberikan hasil ukur yang terpercaya. Untukmenguji tingkat reliabilitas, biasanya digunakan sebuahvariabelsi yang handal atau variabel hadir jika memberikan nilai Cronbach Alpha > 0,60 (Santoso, 2002:200) Hasil uji reliabilitas dapat dilihat pada tabel. 6

Berdasarkan Tabel . 6, dapat diketahui bahwa Alpha Cronbach seluruh instrument lebih besar daripada 0.6. Hal ini menunjukkan bahwa pengukuran tersebut dapat memberikanhasil yang konsistenapabila dilakukan pengukuran kembali terhadap subyek yang sama.

Tabel 6. Uji Reliabilitas

\begin{tabular}{|c|c|c|}
\hline Variabel & $\alpha$ & Keterangan \\
\hline Overconfidence & 0,699 & \\
\hline Illusion of Control & 0,829 & Reliabel $\alpha>0,60$ \\
\hline Pengambilan Keputusan Hutang & 0,752 & \\
\hline
\end{tabular}

Sumber : data diolah

\section{Uji Asumsi Klasik}

Untuk mendapatkan model empiris yang tepat maka koefisien regresi harus memenuhi syarat Best Linear Unbiased Estimation (BLUE). Untuk memperoleh hasil koefisien yang BLUE harus memenuhi asumsi klasik yaitu data berdistribusi normal atau mendekati normal, tidak ada multikolinearitas, dan tidak heteroskedastisitas.

\section{Uji Normalitas}

Uji normalitas bertujuan untuk menguju apakah dalam model regresi, variable dependen dan independent keduanya mempunyai distribusi normal atau tidak. Pengujian normalitas data yangdiujidapat ditentukan dengan One SampleKolmogorov Smirnov Test . Hasil ujinormalitas dapat dilihat pada Tabel.7. 
Tabel 7. Hasil Uji Normalitas dengan Kolmogorov Smirnov Test

\begin{tabular}{|l|l|l|l|}
\hline Variabe & NilaiKolmogorovSmirnov & Sig & Keterangan \\
\hline Unstandardized Residual & 0,702 & 0,707 & Berdistribusi Normal \\
\hline
\end{tabular}

Sumber : data diolah

Berdasarkan hasil pengujian normalitas data sebagaimana dapat dilihat pada Tabel. 7, dapat dinyatakan bahwa nilai unstandardized residual yang diperoleh dari analisis regresi memiliki angka signifikansi lebih besar dari 0,05. Sehingga, model regresi layak dipakai karena telah memenuhi asumsi normalitas.

\section{Uji Multikolineriaritas}

Multikolineriaritas berarti terjadi interkorelasi antar variabel bebas yang menunjukkan adanya lebih dari satu hubungan linier yang signifikan. Apabila koefisien korelasi variabel yang bersangkutan nilainya terletak di luar batas-batas penerimaan (critical value) maka koefisien korelasi bermakna dan terjadi multikolinearitas. Apabila koefisien korelasi terletak di dalam batas-batas penerimaan maka koefisien korelasinya tidak bermakna dan tidak terjadi multikolinearitas.

Tabel 8. Collinearity Statistic

\begin{tabular}{|l|l|l|}
\hline Variabel & VIF & Keterangan \\
\hline Overconfidence & 1,728 & VIF $<10$ \\
Illusion of Control & 1,728 & Tidak ada multikolinearitas \\
\hline
\end{tabular}

Sumber : data diolah

Berdasarkan hasil analisisCollinearity Statistic diketahui bahwadalam model tidak terjadi multikolinearitas.

\section{Uji Heteroskedastisitas}

Pengujian ini dilakukan untuk mengetahui apakah dalam sebuah modelregresi terjadi ketidaksamaan varian darisatu pengamatan ke pengamatan yang lain.Dasarpengambilan keputusan adalah sebagaiberikut jika ada (points) yang adamembentuk suatu pola tertentu yangteratur (bergelombang, melebar, kemudianmenyempit), maka telah terjadiheteroskedastisitas

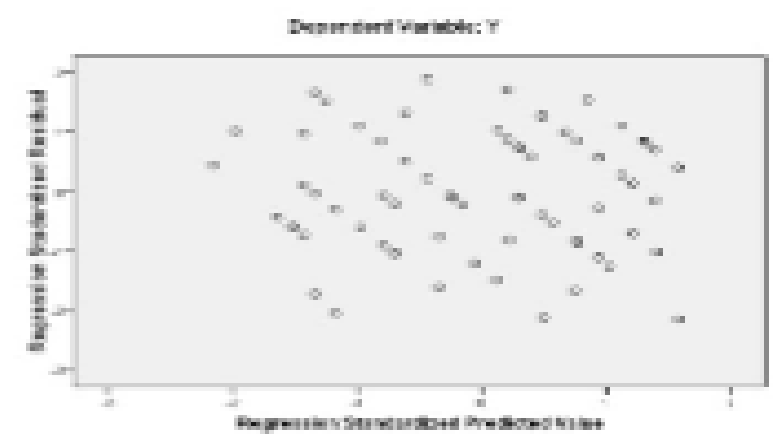

Gambar 2 Hasil Uji Heteroskedastisitas Sumber: data diolah

Hasil analisis dari grafik scatterplots pada Gambar 2 terlihat titiktitik menyebar secara acak, tidakmembentuk suatu pola tertentu yang jelas,serta tersebar baik di atas maupun dibawah angka 0 pada sumbu Y. Hal iniberarti tidak terjadi heteroskedastisitaspada model regresi. 


\section{Analisis Regresi Linier Berganda}

Pengujian regresi linear bergandaberguna untuk mengetahui tingkatpengaruh variabel independen (factordemografi dan faktor psikologi) terhadapvariabel dependen (keputusan berwirausaha). Berdasarkan pengujiandengan bantuan program SPSS forWindows 17.0 diperoleh hasil yang dapatdisajikan dalam tabel berikut.

Tabel 9. Hasil Perhitungan Regresi Linear Berganda

\begin{tabular}{|l|l|l|l|l|}
\hline Variabel & Koef. Regresi & thitung & Sig. & Keterangan \\
\hline Konstanta & $-0,467$ & $-0,539$ & 0,592 & - \\
$\mathrm{X} 1$ & 0,166 & 2,650 & 0,010 & Signifikan \\
$\mathrm{X} 2$ & 0,521 & 7,998 & 0,000 & Signifikan \\
\hline & & & & \\
\hline & & R & & 0,845 \\
& & $R$ Square & & 0,715 \\
& F hitung & & 85,102 \\
& Sig & & 0,000 \\
\hline
\end{tabular}

Sumber: data diolah

Berdasarkan hasil tersebut dapat diperoleh persamaan regresi linier berganda sebagai berikut:

$$
\mathrm{Y}=\mathbf{- 0 , 4 6 7 + 0 , 1 6 6 X 1 + 0 , 5 2 1 \times 2 + e}
$$

Interpretasi atas hasil analisis tersebut dapat dinyatakan sebagai berikut:

1. Konstanta sebesar $-0,467$, menunjukan besaran keputusan untuk berhutang pada saat factor Overconfidence dan Illusion of Controlsama dengan nol. Dalamhal ini keputusan berhutang akanmengalami penurunan tanpa ketigavariabel tersebut yang disebabkanoleh faktor lain.

2. $\mathrm{b} 1=0,166$, artinya apabila variable faktor Overconfidence sama dengan nol, maka peningkatan variabel factor Overconfidence akan meningkatkankeputusanberwirausaha.

3. $\mathrm{b} 2=0,521$ artinya apabila variable faktor Illusion of Control, sama dengan nol,maka peningkatan variabel factor Illusion of Control akan meningkatkankeputusan berwirausaha.

\section{Koefisien Determinasi Berganda (R2)}

Nilai koefisien determinasi berganda(R2) dimaksudkan untuk mengetahuibesarnya sumbangan dari variabel bebasterhadap variabel terikat. Nilai koefisiendeterminasi terletak antara 0 dan 1.Apabila R square atau R2 = 1, maka garisregresi dari model tersebut memberikansumbangan sebesar $100 \%$ terhadapperubahan variabel terikat. Apabila R2 $=0$, maka model tersebut tidak bisamempengaruhi atau tidak bisamemberikan sumbangan terhadapperubahan variabel terikat. Kecocokanmodel akan semakin lebih baik apabila mendekati satu.

Berdasarkan hasil analisis yang bisa dilihat pada Tabel 9 diperoleh hasil koefisien determinasi berganda (R2) sebesar 0,715 , hal ini berarti $71,5 \%$ perubahan keputusan berwirausaha dipengaruhi oleh variabel factor demografi dan faktor psikologi, sedangkan sisanya sebesar $28,5 \%$ disebabkan oleh faktor lain seperti motivasi, dukungan keluarga, modal, dan lainnya yang tidak termasuk dalam persamaan regresi yang dibuat.

\section{Pengujian Secara Parsial (Uji t)}

Pengujian ini dimaksudkan untuk mengetahui pengaruh masing-masingvariabel independen terhadap variable dependen. Caranya adalah dengan membandingkan nilai probabilitas $(\alpha)$ 
dengan tingkat signifikansi $\alpha=5 \%$. Masing-masing variabel bebas dikatakan mempunyai pengaruh yang signifikan (nyata) apabila probabilitas $\leq 5 \%(\alpha)$. Hasil perhitungan uji tengan menggunakan program SPSS for Windows dapat dilihat pada Tabel 1.6.

Tabel 10. Ringkasan Hasil Uji t

\begin{tabular}{|l|l|l|l|}
\hline Variabel & thitung & Sig. & Keterangan \\
\hline X1 & 2,650 & 0,010 & H1diterima \\
X2 & 7,998 & 0,000 & H2 diterima \\
\hline
\end{tabular}

Sumber: data diolah

Berdasarkan table diatas diketahui besarnya pengaruh masing-masing variabel bebas terhadap variable terikat sebagai berikut:

1. Pengaruh Variabel factor Overconfidence $\left(X_{1}\right)$ terhadap Keputusan Berhutang $(Y)$ Berdasarkan Tabel 10 dapat diketahui bahwa signifikansi variable faktor Overconfidence $\left(X_{1}\right)<\alpha$ yaitu $0,010<0,05$. Karena tingkat probabilitasnyalebih kecil dari 5\%, maka H0 ditolak, berarti secara parsial variabel factor Overconfidence $\left(X_{1}\right)$ mempunyai pengaruh terhadap keputusan berhutang $(\mathrm{Y})$. Sehingga, hipotesis yang menyatakan da penharuh factor Overconfidence pada pelaku UMKM sektot makanan dikota bandung terbukti kebenarannya ( $\mathrm{H}_{1}$ diterima).

2. Pengaruh Variabel factor Illusion of Control $\left(X_{2}\right)$ terhadap Keputusan Berhutang $(Y)$ Berdasarkan Tabel 10 dapat diketahui bahwa signifikansi variable faktor Illusion of Control $\left(X_{2}\right)<\alpha$ yaitu $0,010<0,05$. Karena tingkat probabilitasnyalebih kecil dari 5\%, maka H0 ditolak, berarti secara parsial variabel factor Illusion of Control $\left(X_{2}\right)$ mempunyai pengaruh terhadap keputusan berhutang (Y). Sehingga, hipotesis yang menyatakan da penharuh factor Illusion of Controlpada pelaku UMKM sektot makanan dikota bandung terbukti kebenarannya $\left(\mathrm{H}_{2}\right.$ diterima).

\section{Hasil Uji F}

Pengujian ini bertujuan untukmengetahui faktor Overconfidence dan factor Illusion of Control secara simultan terhadapKeputusan Berhutang. Penelitian inidilakukan dengan menggunakan tingkatsignifikan 0,05. Secara bersama-samavariabel faktor Overconfidence dan factor Illusion of Controlakan terbukti berpengaruhsecara signifikan terhadap Keputusan Berhutang jika probabilitas $\leq 0,05$.Sebaliknya jika probabilitas $>0,05$ makavariabel faktor Overconfidence dan factor Illusion of Controltidak berpengaruh secarasignifikan terhadapKeputusan Berhutang. Adapun hasil uji F secararingkasa dapat dilihat dalam Tabel 11.

Tabel 11. Hasil Perhitungan Uji

\begin{tabular}{|c|c|c|c|c|}
\hline $\begin{array}{c}\text { Dependent } \\
\text { Variable }\end{array}$ & $\begin{array}{l}\text { Independent } \\
\text { Variable }\end{array}$ & R Square & Fhitung & Sig \\
\hline Y & X1, X2 & 0,715 & 85,102 & 0,000 \\
\hline
\end{tabular}

Sumber: data diolah

Berdasarkan Tabel 11 dapat dilihatbahwa nilai probabilitas signifikansi uji F lebih kecil dari $0,05(0,000<0,05)$,maka variabel faktor Overconfidence dan factor Illusion of Control secara simultan berpengaruh terhadap Keputusan Berhutang., dalam hal ini H0 ditolak. Sehingga dapat dinyatakan bahwa pengaruh faktor Overconfidence dan factor Illusion of Control secara simultan terhadap Keputusan Berhutang pada pelaku UMKM sector makanan dikota bandung. 


\section{PEMBAHASAN}

Penelitian ini dilakukan dengan tujuan mengetahui faktor Overconfidence dan factor Illusion of Control terhadap Keputusan Berhutang pada pelaku UMKM sector makanan dikota bandung. Pengujian statistic secara parsial (individu) dilakukan dengan menggunakan uji t.

\section{Pengaruh faktor Overconfidence terhadap Keputusan Berhutang}

Hasil uji regresi menujukan variable faktor Overconfidence berpengaruh positif dan signifikan terhadap Keputusan Berhutang. Hal iniberarti pengusaha UMKM memang memerlukan bantuan untuk memulihkan usahanya yang terpuruk akibat adanya pandemic covid 19. Pengambil keputusan ini dilakukan berdasarkan pertimbangan beban bunga yang harus ditanggungdan jangka waktu pengembalian yang harus tepat waktu. Rasionalitas yang digunakan dalampengambilan keputusan hutang dilatarbelakangi oleh usia sebagian besar pelaku UMKM sector makanan di Kota Bandungmasih produktif berkisar antara 36 sampai 40 tahun, sebagian besar perempuan, dengan tingkat pendidikan sebagian besarlulusan perguruan tinggi.Temuan ini memperluas studi tentang keuangan perilaku. Lebih jelasnya, penelitian inimenghasilkan temuan bahwa Variabel Overconfidence yang memiliki 3 indikator, yaitu:Kemampuan melunasi hutang, Kemampuan menanggung beban bunga dan Percaya mampumelunasi sesuai dengan jangka waktu pengembalian yang telah ditetapkan, berpengaruhsignifikan terhadap Pengambilan keputusan hutang.

\section{Pengaruh faktor Illusion of Control terhadap Keputusan Berhutang}

Hasil uji regresi menujukan variable faktor Illusion of Control berpengaruh positif dan signifikan terhadap Keputusan Berhutang. Halini berarti semakin besar keyakinan pelaku UMKM dalam mempengaruhi keputusan makasemakin besar peranannya dalampengambilan keputusan hutang. Semakin terlibat aktifpelaku UMKM dalam menentukanpilihan sehingga merasa familiar terhadap hutang dengandidukung informasi yang cukup,maka akan dapat menentukan keputusan terhadap hutangsebagai sumber pendanaan.Adanya pengaruh Illusion of Control terhadap pengambilankeputusan hutang didasari olehusia sebagian besar pelaku UMKM sector makanan yang masih produktifberkisar antara36 sampai 40 tahun, sebagian besar wanita, dengan tingkat Pendidikan sebagian besar lulusan perguruan tinggi, serta lama usaha yang lebih dari 5 tahun.Temuan ini membuktikan bahwa semakin banyak pengalaman dalam pengelolaan UMKMmembuat pelaku semakinyakin mampu mengendalikan atau mempengaruhi hasil suatukeputusan yang diambil.

\section{KESIMPULAN DAN SARAN}

Berdasarkan pengujian hipotesis, hasil pembahasan dan temuan penelitian, dapat dikemukakan beberapa kesimpulan sebagai berikut:

1. Overconfidence berpengaruh signifikan terhadap pengambilan keputusan hutang yang dilakukan oleh pelaku sekaligus pemilik UMKM. Ini berarti pengusaha UMKM memang perlu dibantu dalam menstabilkan usahanya di saat era pandemic covid-19. Langkah yang tepat telah dilakukan pemerintah kota Bandung dengan memberikan pinjaman dana usaha kepada pelaku UMKM dikota Bandung. Ini sangat membantu mereka dalam mengatasi masalah disaat krisis.

2. Illusion of Control berpengauh signifikan terhadap pengambilan keputusan hutang. Hal ini berarti semakin besar keyakinan pelaku UMKM sector makanan dalam mempengaruhi keputusan makasemakin besar peranannya dalam pengambilan keputusan hutang. Semakin terlibat aktif pelaku UMKM sector makanan dalam menentukan pilihan, sehingga merasa familiar terhadap hutang dandidukung informasi yang cukup, 
maka akan dapat menentukan keputusan terhadappengambilan hutang sebagai sumber pendanaan.

Berdasarkan pada hasil dan kesimpulan penelitian ini, dapat dikemukakan saransaran yang menjadi rekomendasi pada penelitian berikutnya.

1. Diharapkan penelitian mendatang tidak hanya melihat dua psychological bias saja. Masih ada psychological bias yang lain mungkin saja juga berpengaruh dalam keputusan pengambilan hutang, seperti: Avaibility,excesstive optimism, representativeness, dan affect.

2. Penelitian yang akan datang diharapkan sampel penelitian tidak hanya terbatas pada UMKM sektor makanan saja, karena masih banyak UMKM sector lain yang berkembang di masyarakat, seperti UMKM kerajinan bambu dan kayu dll.

\section{DAFTAR PUSTAKA}

Bell, D. 1992. Regret in Decision Making Under Uncertainty.Operation Research, Vol. 30, No. 5,pp. 961-981.

Darmawan. 2005. Faktor-Faktor yang Dapat Menentukan Keberhasilan Usaha Industri Mikro, Kecil dan Menengah Sektor Kerajinan di Kotamadya Yogyakarta. Tesis.Pascasarjana Universitas Indonesi

De Bondt, W. et al. 2008. Behavioral Finance: Quo Vadis ?.Journal of Applied Finance; Fall 2008; 18, 2; ABI/INFORM Research.

Eichholtz and Yonder. 2011. CEO Overconfidence, Corporate Investment Activity, and Performance: Evidence from REITs. Working Paper.Faculty of Business and Economics. Maastricht University Netherlands.

Ferdinand, Augusty. 2011. Metode Penelitian Manajemen. BP. UNDIP. Semarang.

Forbes, William.2009. Behavioural Finance.First Edition.John Wiley \& Sons Ltd.

Grinblatt and Keloharju. 2009. Sensation Seeking, Overconfidence, and Trading Activity.TheJournal of Finance, Vol. LXIV, No. 2, pp. 549-578.

Friedman, Henry. 2007. Does Overconfidence Affect Entrepreneurial Investment ?.Wharton Research Scholars Journal. 5-1-2007

Gibson, B. 2001.Definition of Small Business.Final Report.The University of New Castle. 5,April.

Gumanti, Ary Tatang. 2009, Behavior Finance: Suatu Telaah. Usahawan No. 1/Th,XXXVIII. Hastuti.2003. Upaya Penguatan Usaha Mikro dalam Rangka Peningkatan Ekonomi Perempuan(Sukabumi, Bantul, Kebumen, Padang, Surabaya, Makassar). Jakarta: Lembaga PenelitianSmeru.

Ishikawa, Masaya and Takahashi, Hidetomo. 2010. Overconfident Managers and External FinancingChoice. Review of Behavioral Finance, Vol. 2, pp. 37-58

Kuncoro, M. 2000. Usaha Kecil di Indonesia: Profil, Masalah dan Strategi Pemberdayaan. STIEYogyakarta

Lintner, G. 1998. Behavioral Finance: Why Investors Make Bad Decisions.The Planner, 13 (1), 7-8. Vol. 68, No.4.

Luong, Le Phuoe dan Ha, Doan TT. 2011. Behavioral Factors Influencing Individual Investors' Decision Making and Performance. Thesis.Umea School of Business.

Nofsinger, J.R. 2005.The Psychology of Investing.Second Edition. New Jersey:PearsonPrenticeHall, Upper Saddle River.

Pompian, Michael M.2006.Behavioral Finance and Wealth Management.John Wiley \& Sons,Inc.

Ramiah; Zhao; Graham and Moosa. 2012. Behavioural Aspects of Working Capital Managers. School of Economics, Finance and Marketing, RMIT University, Australia. 
Reid, G. 2007. Small Firms Actions and Their Survival Probabilities CRIEFF. Department of Economic.University of St. Andrews.

Shefrin, H.2007. Behavioral Corporate Finance: Decision thar Create Value. Mc GrwallHill/Irwin.

Supramono; Kaudin; Mahastuti dan Damayanti. 2010. Desain Penelitian Keuangan Berbasis Perilaku. Penerbit: Pusat Studi Keuangan Berbasis Perilaku Fakultas Ekonomi UKSW Salatiga.

Supramono dan Putlia, Nancy. 2010. Persepsi dan Faktor Psikologis dalam Pengambilan Keputusan Hutang. Jurnal Keuangan dan Perbankan, Vol. 14, No. 1 Januari 2010, hal.24-35.

Susanti, I., Syairozi, M. I., \& Lukman, H. Y. W. (2021). Analisis Sistem Manajemen Dalam Pengelolaan Bumdes Di Desa Bluluk. Jurnal Sains Sosio Humaniora, 5(2), 701-710.

Syairozi, M. I. (2017). Prospek Pengembangan Ilmu Ekonomi Islam di Indonesia dalam Prespektif Filsafat Ilmu (Sebuah Kajian Epistemik). JPIM (Jurnal Penelitian Ilmu Manajemen), 2(1), 16-Halaman.

Wijaya, K., \& Syairozi, M. I. (2020). Analisis perpindahan tenaga kerja informal Kabupaten Pasuruan. Jurnal Paradigma Ekonomika, 15(2), 173-182. 